\title{
Contrasting bee pollination in two co-occurring distylic species of Cordia (Cordiaceae, Boraginales) in the Brazilian semi-arid Caatinga: generalist in $C$. globosa vs. specialist in C. leucocephala
}

\author{
ISABEL C. MACHADO ${ }^{1}$, ARIADNA V. LOPES $^{1}$ and MARLIES SAZIMA ${ }^{2}$ \\ ${ }^{1}$ Departamento de Botânica, CCB, Universidade Federal de Pernambuco \\ Rua Prof. Nelson Chaves s/n, Cidade Universitária, 50372-970 Recife, PE, Brasil \\ ${ }^{2}$ Departamento de Botânica, Instituto de Biologia, Universidade Estadual de Campinas \\ Rua Monteiro Lobato, 970, Cidade Universitária “Zeferino Vaz”, 13083-970 Campinas, SP, Brasil
}

Manuscript received on June 4, 2009; accepted for publication on March 31, 2010

\begin{abstract}
In this study we compare the reproductive biology of Cordia globosa and C. leucocephala (Cordiaceae, Boraginales; formerly referred to Boraginaceae) to understand the functioning of the floral morphs and the relations with their effective pollinators. The species are synchronopatric, distylic, and self-incompatible. Though they share melittophilous traits, the main visitor and pollinator of C. globosa was the generalist and exotic bee Apis mellifera, while the only one of $C$. leucocephala was the oligoletic bee Ceblurgus longipalpis. These two latter species are restricted to the Caatinga of NE Brazil, contrasting with the wide distribution of Cordia globosa. While the fruit-set for C. globosa was high, independently if the pollen donor/stigma receptor was a pin (long-styled) or thrum (short-styled) individual, in C. leucocephala the fruit-set was low and occurred only when a thrum individual was the pollen donor. This raises the possibility of this species moving towards dioecy. The high natural fruit-set of C. globosa confirms the generalist bee as its effective pollinator. The low fruit-set after manual crosses in C. leucocephala may be due to low pollen viability. Additionally, the low natural fruit-set (two times lower than after crosses) may be related with the foraging behavior of the specialist pollinator.
\end{abstract}

Key words: Apis mellifera, Caatinga, Ceblurgus longipalpis, Cordia globosa, Cordia leucocephala, dry forest, heterostyly, oligolecty.

\section{INTRODUCTION}

Many species in the Boraginaceae are known to have heteromorphic self-incompatibility system. The occurrence of distyly in Cordia L. (traditionally Boraginaceae, but now Cordiaceae) was first recorded by Darwin (1877). Heterostyly is a prominent part of the reproductive system in the genus (Opler et al. 1975, Taroda and Gibbs 1986a, Boshier 1995, Machado and Loiola 2000), although homostylic and functionally dioecious species are also known (Bawa 1974, Opler et al. 1975, Gibbs and Taroda 1983).

Correspondence to: Isabel Cristina Machado

E-mail: imachado@ufpe.br
The first descriptions of pollination in Cordia date to the classical publications of Knuth (1898-1905) and Vogel (1954). Bees and butterflies proved to be the main pollinators, although pollination by hummingbirds, beetles, wasps, flies, and bats has been also recorded (Alvarez and Quintero 1970, Percival 1974, Opler et al. 1975, Dobat and Peikert-Holle 1985, Askins et al. 1987, Machado and Loiola 2000).

Cordia globosa Kunth and C. leucocephala Moric. belong to the sub-genus Varronia, but have different distribution amplitudes (Taroda and Gibbs 1986a, b). Cordia globosa is widely distributed, occurring in Florida, the Caribbean region, and from Central America to the 
northeastern region of South America (Johnston 1949). In Brazil it is only found in the Caatinga (Taroda and Gibbs 1986a, b, Melo and Sales 2005). Contrastingly, Cordia leucocephala is endemic to northeastern Brazil and is restricted to the Caatinga areas and sandy soils (Taroda and Gibbs 1986b, Giulietti et al. 2002, Melo and Sales 2005). Despite its restricted distribution, it has commercial potential as a grazing and ornamental species (Andrade-Lima 1989).

While there are no reports about the pollinators for C. globosa, for C. leucocephala an oligolectic bee species is suspected to be its pollinator. In 1993, Urban and Moure described a new genus and species (Ceblurgus longipalpis - Halictidae) from specimens that visited exclusively the flowers of Cordia leucocephala in the Caatinga areas in Pernambuco (I.C. Machado, unpublished data) and Bahia States (C.F. Martins, unpublished data), Brazil. Aguiar and Martins (1994) later captured a large number of individuals of $C$. longipalpis in Paraíba State that almost exclusively visited C. leucocephala flowers.

Because of the specific relations between Cordia leucocephala and Ceblurgus longipalpis, and the total lack of information about the pollinators of C. globosa, we aimed to study the floral biology and the reproductive system of these two synchronopatric species. We also described the structure and functioning of the two floral morphs of both species, as well as the relations to their effective pollinators.

\section{MATERIALS AND METHODS}

\section{STUdy Sites}

Field work was carried out mainly in Sítio Riacho, in the municipality of Alagoinha, Pernambuco State $\left(08^{\circ} 27^{\prime} \mathrm{S}\right.$ and $36^{\circ} 46^{\prime} \mathrm{W}$ ), Brazil, from 1984 to 1988 . Additional data on floral visitors of Cordia leucocephala were gathered in 1999 in the municipality of Pesqueira, also in Pernambuco, as well as in 2003 in a protected area within the Fazenda Almas, municipality of São José dos Cordeiros, Paraíba State $\left(7^{\circ} 28^{\prime} 45^{\prime \prime} \mathrm{S}\right.$ and $\left.36^{\circ} 54^{\prime} 18^{\prime \prime} \mathrm{W}\right)$, northeastern Brazil. Field observations of focal plants for both species totalized ca. 260 hours. The vegetation in the study areas is classified as Caatinga, which is a deciduous, thorny, scrub vegetation (Andrade-Lima 1981, see also Machado and Lopes 2003, 2004 for details).
The main study site (Alagoinha), is located at $762 \mathrm{~m}$ a.s.l. and has a very hot, semi-arid climate (BSs'h' - Köppen classification). The average annual temperature is about $24^{\circ} \mathrm{C}$ (Jacomine et al. 1973), and the annual rainfall ranges between 600 to $700 \mathrm{~mm}$, with a marked dry season that lasts ca. 5 months. The Fazenda Almas site is located in a geomorphological depression zone, 200 to 300 meters below the level of the neighboring Borborema plateau, in a region known as "cariris paraibanos". The climate is also semi-arid, with irregular annual rainfall totaling less than $600 \mathrm{~mm}$, high solar irradiation levels, low relative humidity, and temperatures ranging between 26 to $30^{\circ} \mathrm{C}$ (Prado 2003). The dry season is very pronounced and lasts from six to nine months, sometimes extending to 10 months (Governo do Estado da Paraíba/SE/UFPB 1989).

Voucher specimens of both Cordia species were housed at the Herbarium UFP at the Universidade Federal de Pernambuco (numbers UFP 04267 and 04276).

\section{Plant And Flower Features}

The phenology of individual flowers, ramets, and of the entire populations of both Cordia species were studied by monitoring 20 individuals of C. globosa and 20 clumps of 3-4 individuals of $C$. leucocephala (10 with pin and 10 with thrum flowers) during four consecutive years.

Data were recorded concerning the initiation, sequence, and duration of anthesis, as well as floral color and scent emission (or lack of it), floral morphometry, and place and type of the resource. Corolla length and diameter, as well as stigma and anther heights (both measured from the base of the ovary) were measured in 20 flowers from different individuals of each morph. The length of style and filaments and the distance between the stigma and the anthers of both morphs ( $\mathrm{n}=$ 20 flowers each) were measured in order to determine the function, reciprocity, and complementarity of the morphs, and the effects of morphometric differences on pollination.

We attempted to collect nectar from 20 flowers (bagged at pre-anthesis) using a graduated glass capillary tube and micro-syringes ( 5 and $10 \mu \mathrm{l})$ for measuring volume and sugar concentration (using a handheld temperature-compensated refractometer, Dafni et 
al. 2005). Flowers and buds used for stereomicroscopic examinations were fixed in alcohol $70 \%$, and schematic drawings were made using a stereomicroscope with camera lucida.

Pollen size and morphology were analyzed in Cordia leucocephala to compare brevistylous and longistylous flowers. Slides containing acetolyzed pollen grains were prepared following proposals of Erdtman (1966), and 25 grains, from at least three slides of each floral morph, were randomly sampled and measured (within one week of slide preparation). Pollen viability was verified by using $2 \%$ acetocarmine (Dafni et al. 2005) $(n=20$ flowers from 10 individuals; 10 of each morph/species).

Controlled pollination experiments (manual selfpollination and intra- and inter-morph cross-pollinations) were carried out to examine the reproductive system of both species. Entire inflorescences were bagged just before anthesis and anther dehiscence. All controlled pollinations were performed one hour after anthesis initiation. Pollen deposition in all manual-pollination experiments was confirmed by visual inspection of the stigmas with a hand lens. Fruit-set after treatments was compared with fruit-set under natural conditions (control).

\section{FLORAL VISITORS}

The behavior (pollination or nectar robbing) of the floral visitors was recorded in the field during observations of focal plants totalizing ca. 100 hours for each species. Observations started at 5:30h a.m. but the visitation time, duration, and frequency of visits were registered from the beginning of anthesis for both species (ca. 7:30h a.m.) until flowers have wilted (ca. 14-15:00h). Photographs were taken of both flowers and bees, and some insects were captured for identification. Vouchers are at the Museu de Zoologia, Universidade Estadual de Campinas-UNICAMP (ZUEC) and at the Laboratório de Biologia Floral e Reprodutiva da Universidade Federal de Pernambuco-UFPE.

\section{RESULTS}

\section{Plant AND Flower Features}

Cordia globosa and C. leucocephala are shrubs, 3-4 m and 1-3 m tall, respectively. At the main study site (Alagoinha), isolated individuals of C. globosa occurred near $C$. leucocephala, which grows in clumps of 3-4 individuals. In addition, individuals of C. leucocephala were recorded at Fazenda Almas, and also along roadsides. Flowering of C. globosa and C. leucocephala was uniform, with one major episode per year in three consecutive years. Flowering of both species overlapped for a period of three to four months, beginning in January/February (March in the fourth year of observation) and ending in April/May. Both species are heterostylous (distylous), with a 1:1 isoplethic ratio of their populations (brevistylous and longistylous individuals).

The flowers of both species are white, tubular (Fig. 1), infundibuliform (funnel-shaped), and disposed in dense inflorescences (glomerules). About two to four (C. globosa) or eight or more (C. leucocephala) open flowers per inflorescence were recorded on any given day, emitting a light, sweet odor in the former species, and being scentless in the latter. Anthesis starts at 07:3008:00h a.m. in both species, the anthers dehisce soon after flower opening, and the stigmas remain receptive until 14:00h (C. globosa) or 15:00h (C. leucocephala). Thus, the flowers are attractive for about six to seven hours. Flowers of $C$. globosa are about four times smaller than those of $C$. leucocephala (Table I). The stamens of C. globosa have glabrous filaments, all of them with equal length in the flowers of the same morph (Table I, Fig. 1C), and are inserted on the corolla tube 2.5 to $3.0 \mathrm{~mm}$ from its base. Contrastingly, in C. leucocephala each morph has three groups of stamens with different filament lengths (Table I), which are inserted on the corolla at different heights (Fig. 1A-B). The basal portions of the filaments and of the corolla tube are covered by trichomes only in the longistylous flowers of C. leucocephala (Fig. 1A). The style is single and terminal, with four stigmatic branches at the apex in both species (Fig. 1). Pollen is spherical, with very different sizes between the two floral morphs. Pollen of the brevistylous flowers are significantly larger than those of the longistylous flowers (Table I). Pollen viability for both types of flowers is ca. $98 \%$ in C. globosa, while in C. leucocephala it is about $60 \%$. The nectary is located at the base of the ovary (Fig. 1), and despite of being much larger in C. globosa (Fig. 1C), both species secrete very small, and scarcely measurable, amounts of nectar. In the longistylous flowers of C. leucocephala, 
TABLE I

Measurements (mean \pm SD, mm) of short- and long-styled flowers of Cordia globosa and C. leucocephala, and equatorial diameter (in polar view, $\mu \mathrm{m}$ ) of pollen grains (plants from a Caatinga area, Pernambuco State, Brazil).

\begin{tabular}{c|c|c|c|c}
\hline Species & $\begin{array}{c}\text { Corolla } \\
\text { (length } \times \text { width) }\end{array}$ & Filaments & Style* & $\begin{array}{c}\text { Pollen size } \\
\text { (equatorial diameter) }\end{array}$ \\
\hline C. globosa & & & & \\
\hline Short-styled & $6.9 \pm 0.4$ & $3.5 \pm 0.4$ & $3.7 \pm 0.3$ & $47.3 \pm 0.7 \mu \mathrm{m}(45-50 \mu \mathrm{m})$ \\
Long-styled & $7.0 \pm 0.2$ & $2.0 \pm 0.2$ & $6.4 \pm 0.3$ & $39.5 \pm 0.6 \mu \mathrm{m}(37-42 \mu \mathrm{m})$ \\
\hline C. leucocephala & & & & \\
\hline Short-styled & $35 \pm 0.5 \mathrm{x}$ & $16.6 \pm 1.0 ; 13.3$ & $6.4 \pm 0.5$ & $63.3 \pm 0.5 \mu \mathrm{m}(60-68 \mu \mathrm{m})$ \\
& $28 \pm 1.8$ & $\pm 1.6 ; 9.1 \pm 0.7$ & & \\
Long-styled & $35 \pm 0.9 \mathrm{x}$ & $10.4 \pm 0.5 ; 7.3$ & $14.7 \pm 0.5$ & $51.5 \pm 0.8 \mu \mathrm{m}(44-58 \mu \mathrm{m})$ \\
& $28.4 \pm 0.5$ & $\pm 0.7 ; 5.5 \pm 0.5$ & & \\
\hline
\end{tabular}

*Values correspond to style + stigmatic branches.

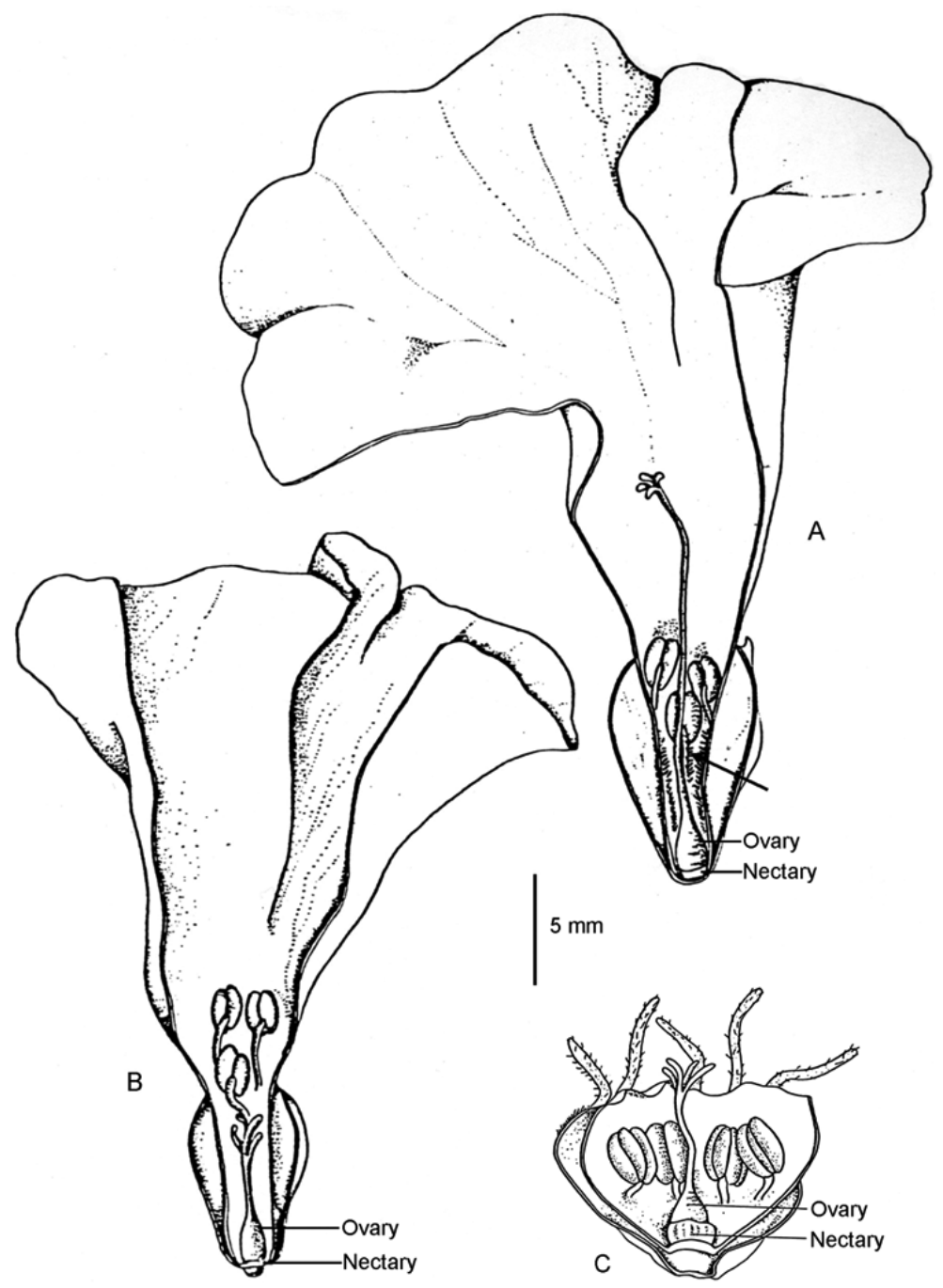

Fig. 1 - Schematic longitudinal sections showing the reproductive structures and the nectary of longistylous (A) and brevistylous (B) flowers of Cordia leucocephala (arrow points to trichomes), and longistylous flowers of C. globosa (C). 
nectar is spread among the trichomes at the base of the filaments (Fig. 1).

Results of pollination experiments are summarized in Table II. In both species, manual crosses between the same floral morph did not cause fruit-set. In C. globosa, reciprocal crosses between different floral morphs resulted in a fruit-set of $80 \%$ and $70 \%$, while under natural conditions fruit-set was ca. $50 \%$. In C. leucocephala, fruit-set was very low under natural conditions $(5 \%)$. Low levels of fruit-set, though two-fold higher $(10 \%)$, were also obtained after intermorph crosses and only when longistylous flowers were the pollen receptors (Table II).

\section{FLORAL VISITORS}

The main floral visitor and pollinator of C. globosa was the exotic and invasive bee Apis mellifera (Fig. 2A), which is responsible for $60 \%$ of all visits. Visits started at $07: 30 \mathrm{~h}$ and finished at $14: 00 \mathrm{~h}$. Individuals of this species visited several flowers of the same plant, remaining on each flower for about three seconds and contacting anthers and stigma while taking nectar. Many individuals foraged on the same floral group of C. globosa at the same time. Trigona spinipes visited and pollinated $C$. globosa flowers, behaving in a very similar manner as A. mellifera and likewise contacting anthers and stigma during nectar uptake. This species was responsible for about $30 \%$ of all visits. Other sporadic visitors were Xylocopa sp., beetles, and butterflies that only occasionally transferred pollen to the stigma. Contrastingly, only one bee species, Ceblurgus longipalpis (Halictidae, Rophitinae), was registered visiting and pollinating flowers of both morphs of C. leucocephala (Fig. 2B-C). Their visits started at 08:00h, continued at intervals of 10 to 20 minutes, and finished at 15:00h. This species landed on the inner side of the corolla, and moved into the corolla tube to probe for nectar or to take up pollen. At this time, anthers and stigma were in touch with the ventral part of its abdomen and legs. Visits lasted for about five to seven seconds, and generally the bees visited other flowers of the same inflorescence before leaving to visit other individuals in the same clump or in neighboring stands. Visits of $C$. longipalpis occurred during the entire flowering period of C. leucocephala.

\section{DISCUSSION}

Both Cordia species exhibit annual and extended flowering patterns (sensu Newstrom et al. 1994). Extended flowering increases the probability of successful outcrosses, and the observed intra-specific flowering synchrony of both species favors cross-pollination, which is essential for self-incompatible species (Bawa 1983) such as C. globosa and C. leucocephala.

The isoplethic population structure of both Cordia species (about 1:1 distribution of brevi- and longistylous individuals) is common among heterostylous species, and results from a strong diallelic system of self-incompatibility (Vuilleumier 1967, Ornduff 1971, Ganders 1979, Sobrevila et al. 1983, Barrett and Shore 1985, Gibbs 1986, Barrett and Richards 1990, Barrett 1990, 1992).

Heterostyly in Cordia was first recorded by Darwin (1877), and distyly can be considered the most prominent feature in the reproductive system in the genus (Percival 1974, Opler et al. 1975, Gibbs and Taroda 1983, Taimes and Varela 2005). Heterostyly arose independently in a lot of families (Lloyd and Webb 1992), and the occurrence of similar polymorphisms in many heterostylic species suggests that these morphological patterns are important to the reproductive system (Vuilleumier 1967, Ganders 1979, Yeo 1975, Barrett 1992). The most common polymorphisms associated with heterostyly involve pollen size and amount, and the number and size of stigmatic papillae (Ganders 1979, Barrett and Shore 1985, Barrett et al. 2000). In some cases there may also be differences in the shape and size of the corolla tube among the floral types (Ganders 1979).

Thus, the presence of smaller pollen grains in longistylous flowers, contrasting with larger ones in brevistylous, is a common feature of distylous species (Vuilleumier 1967). In C. leucocephala these differences are within the variation range reported by Nowicke and Ridgway (1973) for pollen of Cordia species of the Varronia section.

Furthermore, the presence of trichomes at the basal part of the filaments of the longistylous flowers of C. leucocephala and its absence in brevistylous flowers are also known for Lithospermum obovatum - Boraginaceae (Ganders 1979). According to Johnston (1952), 
TABLE II

Pollination experiments in Cordia globosa and $C$. leucocephala in a

Caatinga area, Pernambuco State, Brazil $(\mathrm{nFI}=$ number of flowers; $\mathrm{nFr}=$ number of fruits; $\% \mathrm{FS}=$ percentage of fruit set), and estimated percentage of fruit set under natural conditions (NC).

\begin{tabular}{l|c|c}
\hline \multicolumn{1}{c|}{ Procedures } & $\begin{array}{c}\text { C. globosa } \\
(\mathrm{nFl} / \mathrm{nFr} / \% \mathrm{FS})\end{array}$ & $\begin{array}{c}\text { C. leucocephala } \\
(\mathrm{nFl} / \mathrm{nFr} / \% \mathrm{FS})\end{array}$ \\
\hline Spontaneous self-pollination & $45 / 0 / 0$ & $20 / 0 / 0$ \\
Cross-pollinations: & & \\
Short-styled* $\times$ Long-styled & $10 / 8 / 80$ & $10 / 1 / 10$ \\
Long-styled* $\times$ Long-styled & $10 / 0 / 0$ & $10 / 0 / 0$ \\
$(\neq$ individuals) & & \\
Long-styled* $\times$ Short-styled & $10 / 7 / 70$ & $10 / 0 / 0$ \\
Short-styled* $\times$ Short-styled & $10 / 0 / 0$ & $10 / 0 / 0$ \\
( $\neq$ individuals) & & \\
NC (control) & ca. 50\% & ca. 5\% \\
\hline
\end{tabular}

* Pollen donor.

this type of dimorphism is very rare and one can speculate that, if these trichomes were present in brevistylous flowers of $C$. leucocephala, they would hamper the deposition and adherence of pollen grains to the stigmatic lobes.

The evident reciprocal correspondence of the style and filaments heights in C. globosa and C. leucocephala is generally associated with cross fertilization mechanisms mediated by pollinators in most of the heterostylous species (Ornduff 1974, Ganders 1979, Barrett et al. 2000, Castro et al. 2004). In some cases, however, this correspondence may not be perfect (Ganders 1979), such as in Cordia curassavica and C. dentata, whose style of the longistylous flowers extends only slightly beyond the anthers, while in the brevistylous ones stigmas and anthers are well separated (Opler et al. 1975).

Like Cordia globosa and C. leucocephala, almost all heterostylic taxa are self-incompatible. In the genus Cordia, self-compatibility has only been reported for $C$. alliodora and $C$. sebestena, with all the other species being either distylous (with strongly associated self-incompatibility systems) or dioecious (Opler et al. 1975). Self-compatibility, though rare, does occur in some heterostylic species such as Oxalis (Oxalidaceae), Hedyotis (Rubiaceae), Pulmonaria (Boraginaceae) (Ganders 1979), and Melochia (Malvaceae) (Martin 1967). The only known heterostylous genus in which all species are self-compatible is Amsinckia (Boraginaceae) (Weller and Ornduff 1977).
Distyly has apparently evolved several times to dioecy in the genus Cordia, with C. inermis and C. colococca being considered as intermediate between distylous and dioecious (Opler et al. 1975). In such situations, the longistylous morph would have become pistillate, while the brevistylous became staminate, and an intermediate phase of cryptic dioecy may occur (Opler et al. 1975, Beach and Bawa 1980).

While in C. globosa the fruit-set was very similar for both types of crosses [Short-styled (S) $\times$ Long-styled (L) and $\mathrm{L} \times \mathrm{S}$ ], in C. leucocephala a fruit-set after manual crosses was obtained only in the $\mathrm{S} \times \mathrm{L}$ cross (with $\mathrm{S}$ as pollen donor), with the reverse cross being unsuccessfull. This raises the possibility of this species moving towards dioecy, as observed for some dioecious species of this and other genera (Beach and Bawa 1980).

Fruit-set under natural conditions was low in $C$. leucocephala, and in many other populations no fruits were registered at all (I.C. Machado personal observation, Andrade-Lima 1989, Taroda and Gibbs 1986b, Melo and Sales 2005, Melo and Andrade 2007). This could be due to two reasons: the low pollen viability $(60 \%)$ and the foraging behavior of the specialist pollinator, which may induce geitonogamy, as discussed below. The low fruit-set after manual crosses in C. leucocephala, though two-times higher than that obtained under natural conditions, could be due to the low pollen viability $(60 \%)$.

Notwithstanding, C. globosa and C. leucocephala 

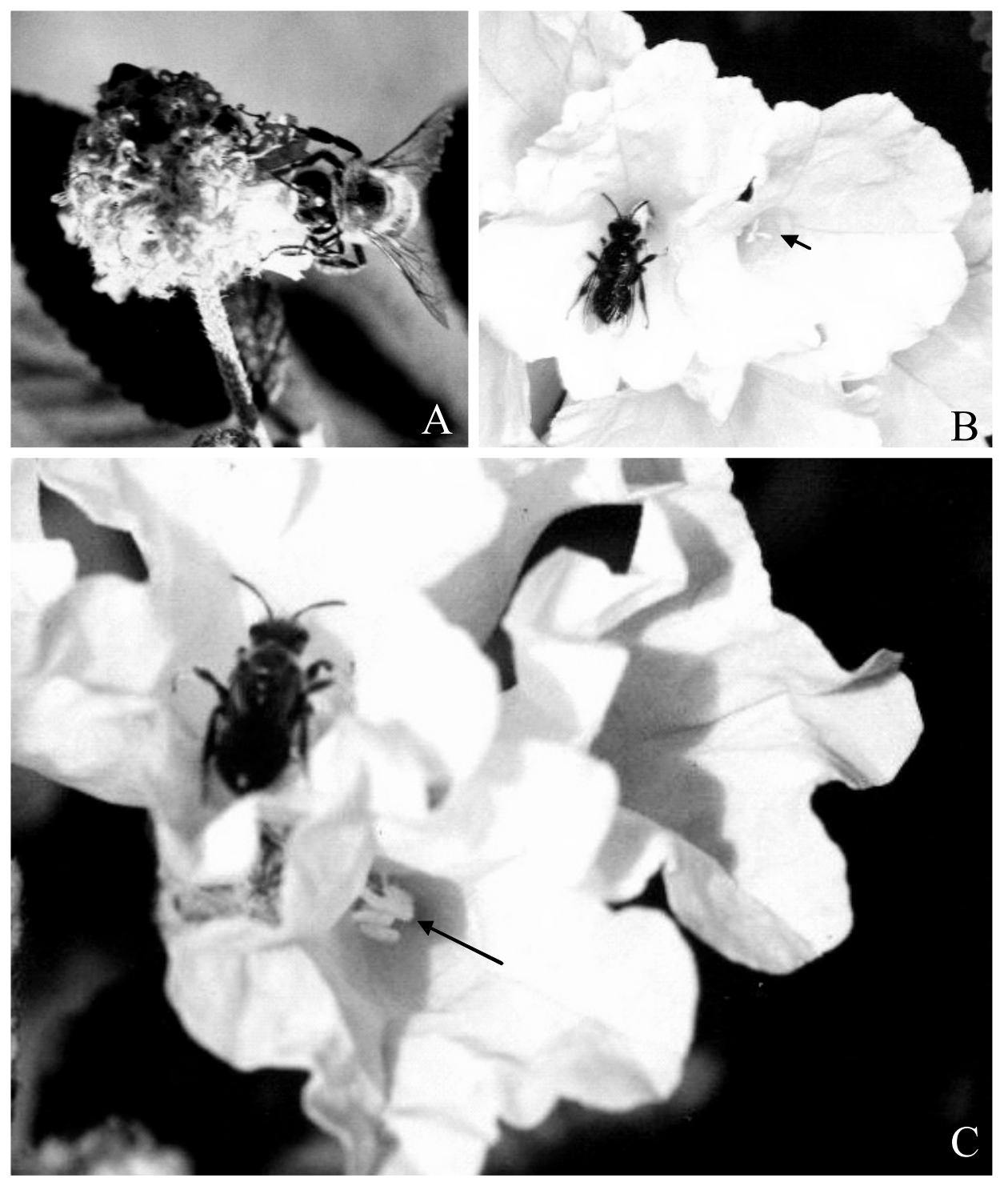

Fig. 2 - Apis mellifera visiting Cordia globosa flower (A), and Ceblurgus longipalpis (HalictidaeRophitinae) visiting longistylous (B) and brevistylous (C) flowers of Cordia leucocephala in a Caatinga area in Pernambuco, Brazil. Arrows point to stigma (B) and anthers (C).

are both melittophilous (sensu Faegri and Pijl 1979), with similar floral traits such as color, form, reward, and time of anthesis, they occur synpatrically, flower synchronously, and are pollinated by bees with very different behaviors. The predominance of generalist bee species, such as Apis mellifera and Trigona spinipes, visiting C. globosa, is possibly related to the small flower size. The exclusiveness of the visits of Ceblurgus longipalpis to C. leucocephala flowers is, however, curious and bizarre, as these flowers are relatively large and could allow visitation by many medium- or large-sized bees whose long tongues would be able to reach the nectar at the base of the corolla tube. The absence of scent and the much reduced nectar volume in C. leucocephala, however, may be responsible for the lack of visitation by long-tongued bees such as Centris and Euglossini species, and the floral tube $(5-7 \mathrm{~mm})$ may limit or exclude access to short/medium-tongued bees like Apis, Trigona, and Xylocopa species. Euglossini bees are in fact very rare in the Caatinga (cf. Lopes et al. 2007), and large-bodied species seek for nectar-rich flowers to supply their energetic requirements. Also, the absence 
of scent in flowers of C. leucocephala may restrict visits of bees like Trigona spp. that are largely attracted by odor (e.g. Nogueira et al. 1999).

The restricted distribution of C. leucocephala (endemic to the Caatinga region of northeastern Brazil) may be strongly correlated with the distribution of the oligoletic bee Ceblurgus longipalpis, its sole visitor and pollinator. Ceblurgus is the only bee genus endemic to the Caatinga region (Aguiar and Martins 1994, Rozen 1997, Zanella and Martins 2003) and its single species, C. longipalpis (Urban and Moure 1993), is restricted to the states of Bahia, Pernambuco, and Paraíba, Brazil (Silveira et al. 2002). The sub-family Rophitinae, in the family Halictidae, comprises bee species that are generally rare, non-social, and morphologically specialized. The bees have a long glossa and labial palps, and collect nutrients from a very restricted number of plant species (Silveira et al. 2002). Ceblurgus longipalpis has elongated mouthparts, apparently as an adaptation to take up nectar from tubular flowers (Zanella and Martins 2003). This matches well with the flower structure of $C$. leucocephala. Besides, both males and females of this bee have been reported to visit almost exclusively $C$. leucocephala in many populations (I.C. Machado unpublished data, C.F. Martins unpublished data, Urban and Moure 1993, Aguiar and Martins 1994, Machado and Lopes 2003, Zanella and Martins 2003, present study). This indicates narrow oligolecty (sensu Cane and Sipes 2006).

The foraging behavior of Ceblurgus longipalpis with repeated visits to flowers of the same inflorescence in C. leucocephala may induce geitonogamy, which could lead to pistil losses since the species is self- and intramorph-incompatible. This could also be one of the causes behind the very low percentage of natural fruitset. In this way, vegetative reproduction in C. leucocephala (see Andrade-Lima 1989) may represent the major mode of reproduction in some patches. A similar situation was recorded for species growing in areas under severe environmental fluctuations (Herrera 1987), such as observed for the semi-arid Caatinga vegetation.

In spite of the existence of plant species with complex flowers and structures that restrict visitation by specialized pollinators (Gómez and Zamora 2006) - as seen in the Caatinga region with Angelonia pubescens and Centris hyptidis (Vogel and Machado 1991), Ange- lonia cornigera and Tapinotaspis nordestina (Machado et al. 2002), and Cordia leucocephala and Ceblurgus longipalpis (present study) - generalist pollination systems are the most common ones (Herrera 1996, Waser et al. 1996, Armbruster et al. 2000, Fenster et al. 2004, Machado and Lopes 2003, 2004, Machado and Sazima 2008).

In fact, Apis mellifera and Trigona spinipes, which both display opportunistic and generalistic behaviors (Proctor et al. 1996, Sazima and Sazima 1989), were responsible for $38.5 \%$ and $46.2 \%$, respectively, of the visits to melittophilous species in the main study area, Alagoinha (Machado and Lopes 2004). In the same study site, both bee species proved to be highly responsible for the strong connectance in the plant/bee pollination network (I.C. Machado unpublished data, Machado and Lopes 2003). The extremely aggressive foraging behavior of A. mellifera and, to a lesser extent, that of T. spinipes (Sazima and Sazima 1989), associated with their generalist foraging behavior, may lead them to experience high visitation rates. This could benefit heterostylic self-incompatible species occurring in the same area such as Cordia globosa (present study) and Melochia tomentosa (Machado and Sazima 2008).

\section{ACKNOWLEDGMENTS}

We thank the taxonomists of the Herbarium IPA for identifying plant species; João Amazonas (UFPE) and Severino Prazeres (in memoriam) for their help during field work. Bee identifications were kindly provided by João Camargo (Ribeirão Preto-USP) and Pe. Jesus Santiago Moure (UFPR). We also thank Maria Regina Barbosa and Zelma Quirino (UFPB/ Peld/CNPq Caatinga Project) who made possible field observations in the RPPN Fazenda Almas-PB; Marlene Barbosa (UFPE) for logistic help in the Herbarium UFP, and Coordenação de Aperfeiçoamento de Pessoal de Nível Superior (CAPES) and Conselho Nacional de Desenvolvimento Científico e Tecnológico (CNPq) for essential financial support.

\section{RESUMO}

Neste estudo comparamos a biologia reprodutiva de Cordia globosa e C. leucocephala para entender a função dos morfos florais e as relações com seus polinizadores efetivos. As espécies são sincronopátricas, distílicas e auto-incompatíveis. 
Embora elas compartilhem atributos melitófilos, o principal visitante e polinizador de C. globosa foi Apis mellifera, abelha generalista e exótica, enquanto o de C. leucocephala foi a abelha oligolética Ceblurgus longipalpis. Essas duas últimas espécies são restritas à Caatinga do Nordeste do Brasil, contrastando com a ampla distribuição de C. globosa. Enquanto a formação de frutos de C. globosa foi alta, independente se o doador ou receptor de pólen era um indivíduo brevi- ou longistilo, em C. leucocephala a formação de frutos foi baixa e ocorreu apenas quando o doador de pólen era brevistilo. Este fato levanta a possibilidade desta espécie estar se movendo em direção à dioicia. A alta formação natural de frutos de C. globosa confirma a abelha generalista como seu polinizador efetivo. A baixa formação de frutos após cruzamentos manuais em C. leucocephala pode ser devida à baixa viabilidade polínica. Adicionalmente, a baixa formação natural de frutos (duas vezes menor que a de cruzamentos) pode estar relacionada com o comportamento de forrageamento do polinizador especialista.

Palavras-chave: Apis mellifera, Caatinga, Ceblurgus longipalpis, Cordia globosa, C. leucocephala, floresta seca, heterostilia, oligoletia.

\section{REFERENCES}

Aguiar CML and Martins CF. 1994. Fenologia e preferência alimentar de Ceblurgus longipalpis Urban \& Moure 1993 (Hymenoptera, Halictidae, Dufoureinae). Rev Nordest Biol 9: 125-131.

Alvarez T AND Quintero LG. 1970. Análisis polínico del contenido gástrico del murciélagos Glossophaginae de México. An Esc Nac Cienc Biol, Mex 18: 137-165.

Andrade-Lima D. 1981. The caatingas dominium. Rev brasil Bot 4: 142-153.

Andrade-Lima D. 1989. Plantas das caatingas, Rio de Janeiro: Academia Brasileira de Ciências, 243 p.

Armbruster WS, Fenster CB ANd Dudash MR. 2000. Pollination "principles" revisited: Specialization, pollination syndromes, and the evolution of flowers. Det Norske Videnskaps-Akademi. I. Matematisk Naturvidenskapelige Klasse, Skrifter, Ny Serie 39: 179-200.

ASKINS RA, ERCOLINO KM AND WALler JD. 1987. Flower destruction and nectar depletion by avian nectar robbers on a tropical tree, Cordia sebestena. J Field Ornith 58: 345-349.

BARRETT SCH. 1990. The evolution and adaptative significance of heterostyly. Tree 5: 144-148.

BARRETT SCH. 1992. Heterostylous genetic polymorphisms: model systems for evolutionary analysis. In:
BARRETT SCH (Ed), Evolution and function of heterostyly, Berlin, Springer-Verlag, p. 1-29.

BARRETT SCH AND RICHARDS JH. 1990. Heterostyly in tropical plants. Mem New York Bot Gard 55: 35-61.

BARRETT SCH AND SHORE JS. 1985. Dimorphic incompatibility in Turnera hermannioides Camb. (Turneraceae). Ann Missouri Bot Gard 72: 259-263.

BARRETT SCH, Jesson LK AND BAKER AM. 2000. The evolution of stylar polymorphisms in flowering plants. Ann Bot 85: 253-265.

BAWA KS. 1974. Breeding systems of tree species of a lowland tropical community. Evolution 28: 85-92.

BAWA KS. 1983. Patterns of flowering in tropical plants. In: Jones CE And LitTle RJ (Eds), Handbook of experimental pollination ecology, New York, Van Nostrand Reinhold, p. 394-410.

BEACH JH AND BAWA KS. 1980. Role of pollinators in the evolution of dioecy from distyly. Evolution 34: 11381142.

BoshIER DH. 1995. Incompatibility in Cordia alliodora (Boraginaceae), a neotropical tree. Can J Bot 73: 445456.

CANE JH AND SIPES S. 2006. Characterizing floral specialization by bees: analytical methods and a revised lexicon for oligolecty. In: WASER NM AND OLLERTON J (Eds), Plant-pollinator interactions, Chicago, The University of Chicago Press, p. 99-122.

Castro CC, Oliveira PEAM and Alves MC. 2004. Breeding systems and floral morphometry of distylous Psychotria L. species in the Atlantic Rain Forest, SE Brazil. Plant Biol 6: 755-760.

Dafni A, Kevan PG And Husband BC. 2005. Practical pollination biology, Cambridge: Enviroquest Ltd., 590 p.

DARWIN C. 1877. The different forms of flowers on plants of the same species, London, John Murray, $352 \mathrm{p}$.

Dobat K And Peikert-Holle T. 1985. Blüten und Fledermäuse, Frankfurt, Waldemar Kramer Verlag, 356 p.

ERdTMAn G. 1966. Pollen morphology and plant taxonomy - Angiosperm, New York, Hafner Publishing Company, $553 \mathrm{p}$.

FAEGRI K AND PiJL L. 1979. The principles of pollination ecology, New York, Pergamon Press, 244 p.

Fenster CB, Armbruster Ws, Wilson P, Dudash MR AND THOMSON JD. 2004. Pollination syndromes and floral specialization. Ann Rev Ecol Syst 35: 375403.

GANDERS FR. 1979. The biology of heterostyly. New Zealand J Bot 17: 607-635. 
GIBBS PE. 1986. Do homomorphic and heteromorphic selfincompatibility systems have the same sporophytic mechanism? Plant Syst Evol 154: 285-323.

GibBs PE And TARoda N. 1983. Heterostyly in the Cordia alliodora - C. trichotoma complex in Brazil. Rev brasil Bot 6: 1-10.

Giulietti AM, Harley RM, Queiroz LP, BARbosa MRV, Bocage Neta, AL and Figueiredo MA. 2002. Espécies endêmicas da caatinga. In: SAMPAIO EVSB, Giulietti AM, Virgínio J And GAmarraRoJAs CFL (Orgs), Vegetação e flora da Caatinga, Recife, Associação Plantas do Nordeste, p. 103-115.

GÓMEZ JM AND ZAMORA R. 2006. Ecological factors that promote the evolution of generalization in pollination systems. In: WASER NM AND OLLERTON J (Eds), Plant-pollinator interactions, Chicago, The University of Chicago Press, p. 145-166.

Governo do Estado da Paraíba / Secretaria de EducAÇão / Universidade Federal dA PARAíba. 1989. Atlas Geográfico do Estado da Paraíba. João Pessoa, Grafset, 100 p.

Herrera CM. 1996. Floral traits and adaptation to insect pollinators: a devil's advocate approach. In: LLOYD DG AND BARRETT SCH, Floral Biology, New York, Chapman \& Hall, p. 65-87.

HerRera J. 1987. Flower and fruit biology in southern Spanish Mediterranean shrublands. Ann Missouri Bot Gard 74: 69-78.

Jacomine PKT, Cavalcanti AC, Burgos N, Pessoa SCP AND SILVEIRA CO. 1973. Levantamento exploratório de solos do Estado de Pernambuco. Ministério da Agricultura, Boletim Técnico n 26, Série Pedologia 14. Recife, SUDENE-DRN, 359 p.

Johnston IM. 1949. Studies in Boraginaceae. XVII. Cordia section Varronia in Mexico and Central America. J Arnold Arb 30: 85-106.

JoHnston IM. 1952. Studies in Boraginaceae. XVII. Noteworthy species, chiefly Asian and South America. J Arnold Arb 33: 62-78.

KNUTH P. 1898-1905. Handbuch der Blütenbiologie. I-III, Leipzig: Engelmann.

Lloyd DG AND WeBB CJ. 1992. The evolution of heterostyly. In: BARRETT SCH (Ed), Evolution and function of heterostyly, Monographs on theoretical and applied genetics, Berlin, Springer-Verlag, p. 151-178.

Lopes AV, Aguiar AV, Machado IC And Rebelo JMM. 2007. A scientific note on the occurrence of Euglossini bees in the Caatinga, a Brazilian tropical dry forest. Apidologie 38: 472-473.
MACHAdo IC AND LoIOLA MI. 2000. Fly pollination and pollinator sharing in two synchronopatric species: Cordia multispicata (Boraginaceae) and Borreria alata (Rubiaceae). Rev brasil Bot 23: 205-311.

Machado IC AND Lopes AV. 2003. Recursos florais e sistemas de polinização e sexuais em Caatinga. In: LEAL IR, TABarelli M And Silva JMC (Orgs), Ecologia e conservação da Caatinga, Recife, Editora Universitária UFPE, p. 515-563.

Machado IC AND Lopes AV. 2004. Floral traits and pollination systems in the Caatinga, a Brazilian tropical dry forest. Ann Bot 94: 365-376.

Machado IC And SAzIMA M. 2008. Pollination and breeding system of Melochia tomentosa L. (Malvaceae), a keystone floral resource in the Brazilian Caatinga. Flora 203: 484-490.

Machado IC, Vogel S And Lopes A. 2002. Pollination of Angelonia cornigera Hook. (Scrophulariaceae) by long-legged, oil-collecting bees in NE Brazil. Plant Biol 4: 352-359.

MARTIN FW. 1967. Distyly, self-incompatibility, and evolution in Melochia. Evolution 21: 493-499.

MElo JIM AND ANDRADE WM. 2007. Boraginaceaea s.l. A. Juss. Em uma área de Caatinga da ESEC Raso da Catarina, BA, Brasil. Acta Bot Bras 21: 369-378.

Melo JIM And SAles MF. 2005. Boraginaceae A. Juss. na região de Xingó: Alagoas e Sergipe. Hoehnea 32: 369 380.

Newstrom LE, Frankie GW and Baker HG. 1994. A new classification for plant phenology based on flowering patterns in lowland Tropical Rain Forest Trees at La Selva, Costa Rica. Biotropica 26: 141-159.

Nogueira PCL, BitTrich V, Shepherd G, Lopes AV AND MARSAIOLI A. 1999. The ecological and taxonomic importance of flower volatiles of Clusia species (Guttiferae). Phytochemistry 56: 443-452.

Nowicke JW AND RIDGWAY JE. 1973. Pollen studies in the genus Cordia (Boraginaceae). Am J Bot 60: 584-591.

Opler PA, BAKer HG AND Frankie GW. 1975. Reproductive biology of some Costa Rican Cordia species (Boraginaceae). Biotropica 7: 234-247.

ORNDUFF R. 1971. The reproductive system of Jepsonia heterandra. Evolution 25: 300-311.

ORNDUFF R. 1974. Heterostyly in South African flowering plants: a conspectus. J South African Bot 40: 169-187.

Percival M. 1974. Floral ecology of coastal scrub in southeast Jamaica. Biotropica 6: 104-129.

Prado D. 2003. As caatingas da América do Sul. In: LeAL IR, TABarelli M And Silva JMC (Orgs), Ecologia e 
conservação da Caatinga, Recife, Editora Universitária, UFPE, p. 3-73.

Proctor M, Yeo P ANd LACK A. 1996. The natural history of pollination, London, Harper Collins Publishers, $479 \mathrm{p}$.

Rozen JR. 1997. South American Rophitinae bees (Hymenoptera: Halictidae: Rophitinae). Am Mus Novitates 3206: 1-27.

SAZIMA I AND SAZIMA M. 1989. Mamangavas e irapuás (Hymenoptera, Apoidea): visitas, interações e conseqüências para polinização do maracujá (Passifloraceae). Rev Bras entomol 33: 109-118.

Silveira FA, Melo GAR and Almeida EAB. 2002. Abelhas Brasileiras: sistemática e identificação, Belo Horizonte, Ministério do Meio Ambiente / PROBIO / PNUD e Fundação Araucária, 253 p.

Sobrevila C, RAMIREZ N AND ENRECH NX. 1983. Reproductive biology of Palicourea fendleri and P. petiolaris (Rubiaceae) heterostylous shrubs of a tropical cloud forest in Venezuela. Biotropica 15: 161-169.

TAIMES MA AND VARELA CW. 2005. Sistema de compatibilidad en la especie distílica Cordia curassavica (JACQ.) R\&S (Boraginaceae). Interciência 30: 431-435.

TAROdA N AND GibBS PE. 1986a. A revision of the Brazilian species of Cordia subgenus Varronia (Boraginaceae). Notes Royal Bot Gard Edinburgh 44: 105-140.

TARoda N AND GibBs PE. 1986b. On the genus Cordia L. (Boraginaceae) in Brazil. 1. A new infrageneric classification and conspectus. Rev brasil Bot 9: 31-42.
URBAN D AND MOURE JS. 1993. Ceblurgus longipalpis gen. e sp.n. Primeiro representante de Dufuoreinae do Brasil (Hymenoptera, Halictidae). An Acad Bras Cienc 65: 101-106.

Vogel S. 1954. Blütenbiologische Typen als Elemente der Sippengliederung, Jena: Gustav Fischer Verlag, 327 p.

Vogel S AND Machado IC. 1991. Pollination of four sympatric species of Angelonia (Scroph.) by oil-collecting bees in NE Brazil. Plant Syst Evol 178: 153-178.

VUILLEUMIER BS. 1967. The origin and evolutionary development of heterostyly in the Angiosperms. Evolution 21: 210-226.

Waser NM, Chittka L, Price MV, Williams NM And OLLERTON J. 1996. Generalization in pollination systems, and why it matters. Ecology 77: 1043-1060.

WELler SG AND ORNDUfF R. 1977. Cryptic self-incompatibility in Amsinckia grandiflora. Evolution 31: 47-51.

YEO PF. 1975. Some aspects of heterostyly. New Phytol 75: $147-153$.

Zanella FCV And Martins CF. 2003. Abelhas da Caatinga: biogeografia, ecologia e conservação. In: LEAL IR, TABARELli M AND Silva JMC (Orgs), Ecologia e conservação da Caatinga, Recife, Editora Universitária, UFPE, p. 75-134. 